\title{
Quality of poultry litter submitted to different treatments in five consecutive flocks $^{1}$
}

\author{
Fernando Carlos Loch², Maria Cristina de Oliveira ${ }^{3}$, Dionatan da Silva², Bruno Nunes \\ Gonçalves $^{4}$, Bruno Fernandes de Faria ${ }^{2}$, June Faria Scherrer Menezes ${ }^{5}$
}

\footnotetext{
1 Pesquisa financiada pela Fundação de Amparo à Pesquisa do Estado de Goiás - FAPEG.

2 Graduação em Medicina Veterinária - Universidade de Rio Verde, Rio Verde, GO.

3 Faculdade de Medicina Veterinária - Universidade de Rio Verde, Rio Verde, GO.

${ }^{4}$ Graduação em Zootecnia - Universidade de Rio Verde, Rio Verde, GO.

${ }^{5}$ Faculdade de Agronomia - Universidade de Rio Verde, Rio Verde, GO.
}

\begin{abstract}
It was evaluated the effects of poultry litter treatment on moisture content, $\mathrm{pH}$, density and volatilized ammonia for five consecutive flocks of broiler chicken breeding. It was used 640 birds per flock as a complete randomized design with eight treatments and four replicates. The treatments were the following: 1 - non-treated litter; 2 - litter submitted to in-house composting; 3 - litter treated with aluminum sulfate; 4 - litter submitted to gypsum; 5 - litter treated with quicklime; 6 - litter treated with dolomitic limestone; 7 - litter treated with zeolite and 8 - litter treated with charcoal. Chopped elephantgrass hay was used as poultry litter in all flocks. Fermentation in the shed increased moisture content of the litters in the second and first flocks on 21 and 42 days of breeding, respectively. There was no difference on density among treatments. Aluminum sulfate reduced $\mathrm{pH}$ of the litters in all flocks at 21 days of breding. On 42 days of breeding, $\mathrm{pH}$ of the litters was reduced in the litters with aluminum sulfate and gypsum in the first, second and forth flocks. On 21 days, aluminum sulfate reduced the volatilized ammonia in the first, third and forth flocks, and on 42 days, there was a reduction of volatilized ammonia in the litters with aluminum sulfate in the forth flock. Aluminum sulfate can improve quality of poultry litter of chopped elephantgrass hay by reducing $\mathrm{pH}$ and ammonia volatilization.
\end{abstract}

Key Words: acidifiers, ammonia volatilization, conditioners

\section{Qualidade da cama de frango submetida a diferentes tratamentos em cinco lotes consecutivos}

\begin{abstract}
RESUMO - Foram avaliados os efeitos do tratamento da cama de frango sobre o teor de umidade, o $\mathrm{pH}$, a densidade e a amônia volatilizada durante cinco lotes consecutivos de criação de frangos de corte. Foram utilizadas 640 aves por lote em delineamento inteiramente casualizado com oito tratamentos e quatro repetições. Os tratamentos foram: 1 - cama não-tratada; 2 - cama submetida à compostagem dentro do galpão; 3 - cama tratada com sulfato de alumínio; 4 - cama tratada com gesso agrícola; 5 - cama tratada com cal virgem; 6 - cama tratada com calcário dolomítico; 7 - cama tratada com zeolita; e 8 - cama tratada com carvão vegetal. O feno de capim-elefante picado foi utilizado como cama de frango em todos os lotes. A fermentação no galpão aumentou o teor de umidade das camas no segundo e primeiro lotes aos 21 e 42 dias de criação, respectivamente. Não houve diferença na densidade entre os tratamentos. O sulfato de alumínio reduziu o $\mathrm{pH}$ das camas em todos os lotes aos 21 dias de criação. Aos 42 dias, o pH das camas foi reduzido nas camas contendo sulfato de alumínio e gesso agrícola no primeiro, segundo e quarto lotes. Aos 21 dias, o sulfato de alumínio reduziu a amônia volatilizada no primeiro, terceiro e quarto lotes e, aos 42 dias, houve redução da amônia volatilizada das camas contendo sulfato de alumínio no quarto lote. O sulfato de alumínio pode melhorar a qualidade da cama de frango de feno de capim-elefante picado, por reduzir o $\mathrm{pH}$ e a volatilização de amônia.
\end{abstract}

Palavras-chave: acidificantes, condicionadores, volatilização de amônia

\section{Introduction}

Litter conditioners might reduce ammonia levels inside poultry houses by reducing $\mathrm{pH}$ and water activity, which affect the survival of litter microorganisms. Amongst conditioners, phosphoric acid, aluminum chloride, superphosphate and sodium bisulfite have been used successfully to reduce litter $\mathrm{pH}$, ammonia volatilization and to inhibit microbial activity (Nagaraj et al., 2007). Do et al. (2005), using ferrous sulfate and aluminum chloride, 
observed that litter $\mathrm{pH}$ have not altered, but moisture content was reduced in the litter treated with ferrous sulfate and ammonia production of litter treated with ferrous sulfate and aluminum sulfate was smaller than that of the control litter.

Alkaline substances (quicklime, gypsum and dolomitic limestone) also interfere with litter quality. Oliveira et al. (2003) made comparisons between new litter and reused litter with and without treatments (gypsum and quicklime) and observed that those substances and the litter reutilization did not interfere with moisture content. Nevertheless, the smallest value for $\mathrm{pH}$ as well as the smallest level of volatilized ammonia were obtained in litter containing gypsum. This is attributed to the $\mathrm{pH}$ reduction and to the gypsum capacity of retaining moisture, which reduces the survival of ammonia-producer bacteria in the litter.

Zeolite is a compound that exchanges cations and it has high affinity and selectivity for $\mathrm{NH}_{4}{ }^{+}$ions. This substance is used as a conditioner in poultry litter, in anaerobic digesters for cow manure and for composting of swine and poultry dejections. Application of $8 \%$ of zeolite reduced the ammonia loss during 56 days of composting poultry dejections in over 44\% (Li et al., 2008).

In-house composting represents litter decomposition performed by aerobic bacteria and fungi (De-Rouchey et al., 2005) which inactivate virus present in the litter by producing heat, ammonia and other products (Macklin et al., 2006; Wilkinson, 2007). Macklin et al. (2006) used in-house composted litter and untreated litter and observed that composting reduced aerobic bacteria due to the inner temperature of the composted product. Besides heat, ammonia might have an important role in bacterial decrease. Miles (2008) used in-house composted litter and reported that ammonia concentration was greater on the compost surface than inside it.

This experiment was performed to evaluate the effects of poultry litter treatment on its moisture content, $\mathrm{pH}$, bulk density and volatilized ammonia during five consecutive flocks of broiler chickens.

\section{Material and Methods}

The experiment was carried out from January to November 2009, at the poultry facilities of Instituto Federal Goiano de Rio Verde, GO. Five consecutive flocks of broiler chickens were bred: the first one from January to March, the second one from April to May, the third on from June to July, the fourth one from August to September and the fifth from October to November.
Each flock was constituted of 640 male chicks at one day of age, with average initial weight of $41.77 \pm 4.03 \mathrm{~g}$. Birds were housed in a conventional poultry house divided into 32 experimental boxes with $2.00 \mathrm{~m}^{2}$ each one, comprising a density of 10 birds $/ \mathrm{m}^{2}$. Birds received pre-initial commercial diet from the first to the seventh day, initial diet from the eighth to the $21^{\text {st }}$ day, growth diet from the $22^{\text {nd }}$ to the $34^{\text {th }}$ day and final diet from the $35^{\text {th }}$ to the $42^{\text {nd }}$ day.

It was used a completely randomized design with eight treatments and four replicates. Treatments were: 1 - untreated litter (control treatment); 2 -in-house composting litter by using plastic tarpaulin; 3 - litter treated with aluminum sulfate $-\mathrm{Al}_{2}\left(\mathrm{SO}_{4}\right)_{3} \cdot 14 \mathrm{H}_{2} \mathrm{O}\left(0.56 \mathrm{~kg} / \mathrm{m}^{2}\right)$ (Moore Junior et al., 2000); 4 - litter treated with gypsum - $\mathrm{CaSO}_{4} \cdot 0,5 \mathrm{H}_{2} \mathrm{O}(40 \%$ of the total weight) (Oliveira et al., 2004); 5 - litter treated with quicklime - $\mathrm{CaO}\left(0.5 \mathrm{~kg} / \mathrm{m}^{2}\right) ; 6$ - litter treated with dolomitic limestone - $\mathrm{CaMg}\left(\mathrm{CO}_{3}\right)_{2}\left(1.5 \mathrm{~kg} / \mathrm{m}^{2}\right) ; 7$ - litter treated with zeolite $\left(\mathrm{Na}_{4} \mathrm{~K}_{4}\right)\left(\mathrm{Al}_{8} \mathrm{Si}_{40} \mathrm{O}_{96}\right) \cdot 24 \mathrm{H}_{2} \mathrm{O}$ (5\% of the total weight; Turan, 2007); and 8 - litter treated with charcoal ( $20 \%$ of the total weight).

Chopped elephant grass hay was used as substrate in all treatments and flocks, at the amount of $11 \mathrm{~kg} / \mathrm{box}$, except for treatments using gypsum, zeolite and charcoal which corresponded to 40,5 and $10 \%$ of the total litter weight, respectively, added only before the entrance of the first flock. On the day before the arrival of the birds, the other conditioners were added to the litter in each flock and they were totally mixed to the litter.

After the withdrawal of each flock, the poultry house remained open for 14 days. During this period, clods were removed from the surface of those litters, revolved every two days, for 14 days. Litters that were submitted to in-house fermentation remained under plastic tarpaulin for 12 days and uncovered for two days, also being revolved for drying. In the following day, birds were placed on litters.

Material harvest for analyses of moisture, $\mathrm{pH}$, bulk density and volatilized ammonia were performed at six points inside the boxes, in order to avoid areas next and under the feeder and drinker. Moisture analysis was performed according to Silva \& Queiroz (2002) and volatilized ammonia, according to Oliveira et al. (2004). For bulk density analysis, a 1,000-mL beaker was filled with poultry litter. Bulk density was considered as the amount of poultry litter in $1,000 \mathrm{~mL}$. Harvests of samples were always performed on the $21^{\text {st }}$ and $42^{\text {nd }}$ day of each flock.

Statistical analysis was performed by using the Sistema de Análises Estatísticas e Genéticas (SAEG) (UFV, 2001) and means were compared by Tukey's test at $5 \%$ of probability. 


\section{Results and Discussion}

Composting under plastic tarpaulin, in comparison to the others litter treatment, resulted in greater $(\mathrm{P}<0.02)$ moisture content for the second and first flocks at 21 and 42 days of breeding, respectively (Table 1 ). This might have occurred because litter was kept covered with a tarpaulin for a period of 12 days at the end of the first flock, which hindered the moisture loss. The greater moisture content of this litter persisted until 21 days of the second flock, which might be due to the reduction on the particles size when litter was reused. Smaller particles absorb less moisture and they easily release it to the environment, becoming dryer (Lien et al., 1998).

Several factors might relate to the moisture content in the litter, such as type of diet, water intake, environmental temperature, ventilation and, mainly, the type of drinker used (Oliveira et al., 2004). Conditioners usually does not affect moisture content, except for those with great capacity to absorb water, like gypsum, dolomitic limestone and zeolite.This effect was not observed in this study, however.

Litter density did not differ ( $\mathrm{P}>0.05)$ among treatments (Table 2), even in litters that presented greater moisture content. As a result, there were no differences concerning volume of litter resulting from each treatment.
Different results were observed by Oliveira et al. (2003), who compared new litter to reused litter, with and without treatment, and it was observed by these authors that substances and litter reutilization did not interfere in the moisture content. The values obtained were $35.58 \%$, $38.41,30.93$ and $40 \%$ for new and reused litters treated with aluminum sulfate, gypsum and quicklime, respectively. Likewise, Oliveira et al (2004) did not find differences in the moisture content of reused litters during three flocks and treated with aluminum sulfate, gypsum, quicklime and superphosphate, in comparison to the untreated litter.

By studying the inclusion of 0, 25, 50 and $75 \%$ of zeolite in composted wood shavings litter, Eleroglu et al. (2005) observed that the moisture content of litter without zeolite inclusion reduced from $36.20 \%$ to $25.20,23.60$ and $21.80 \%$ with the inclusion of 25,50 and $75 \%$ of zeolite, respectively. According to the authors, this result occurred due to the high capacity of zeolite to moisture absorption. Nevertheless, this effect was not observed in this experiment imasmuch as the amount of zeolite used was much smaller than that used by the mentioned authors. However, Nagaraj et al. (2007), studying the effects of sodium bisulfate addition in poultry litter on the day birds were housed and at 21 days of age, reported

Table 1 - Moisture content (\%) of poultry litter submitted to different treatments during five consecutive flocks at 21 and 42 days of breeding

\begin{tabular}{|c|c|c|c|c|c|c|c|c|c|c|}
\hline \multirow[b]{2}{*}{ Treatment } & \multicolumn{2}{|c|}{$1^{\text {st }}$ flock } & \multicolumn{2}{|c|}{$2^{\text {nd }}$ flock } & \multicolumn{2}{|c|}{$3^{\text {rd }}$ flock } & \multicolumn{2}{|c|}{$4^{\text {th }}$ flock } & \multicolumn{2}{|c|}{$5^{\text {th }}$ flock } \\
\hline & 21 & 42 & 21 & 42 & 21 & 42 & 21 & 42 & 21 & 42 \\
\hline Control & 11.31 & $33.25 b$ & $39.05 a b$ & 35.19 & 13.58 & 27.51 & 19.57 & 29.36 & 21.77 & 37.82 \\
\hline Litter + composting & 7.66 & $48.04 \mathrm{a}$ & $40.76 a$ & 36.41 & 16.84 & 24.89 & 21.01 & 23.03 & 19.80 & 27.89 \\
\hline Litter + aluminum sulfate & 8.38 & 28.33b & $24.66 b$ & 35.86 & 12.05 & 26.97 & 20.96 & 26.43 & 23.78 & 38.07 \\
\hline Litter + gypsum & 8.37 & $26.44 b$ & $21.92 b$ & 30.93 & 16.47 & 25.10 & 15.73 & 27.10 & 20.86 & 25.11 \\
\hline Litter + quicklime & 8.05 & $30.90 b$ & $31.18 \mathrm{ab}$ & 35.61 & 16.81 & 23.74 & 18.52 & 33.62 & 21.53 & 35.59 \\
\hline Litter + dolomitic limestone & 9.20 & $28.05 b$ & $24.90 b$ & 27.89 & 14.37 & 20.48 & 16.54 & 29.01 & 21.32 & 30.65 \\
\hline Litter + zeolite & 8.67 & $28.70 \mathrm{~b}$ & $22.15 b$ & 30.31 & 16.72 & 23.61 & 29.82 & 32.86 & 23.86 & 36.99 \\
\hline Litter + charcoal & 6.49 & $26.16 b$ & $27.31 \mathrm{ab}$ & 33.19 & 16.69 & 18.67 & 21.34 & 27.25 & 28.59 & 38.09 \\
\hline Coefficient of variation (\%) & 3.24 & 8.38 & 11.56 & 5.18 & 5.06 & 9.10 & 9.88 & 11.08 & 7.58 & 14.05 \\
\hline
\end{tabular}

Means followed by different letters in columns are different $(\mathrm{P}<0.02)$ by Tukey test.

Table 2 - Density $\left(\mathrm{g} / \mathrm{m}^{3}\right)$ of poultry litters submitted to different treatments during five consecutive flocks at 42 days of breeding

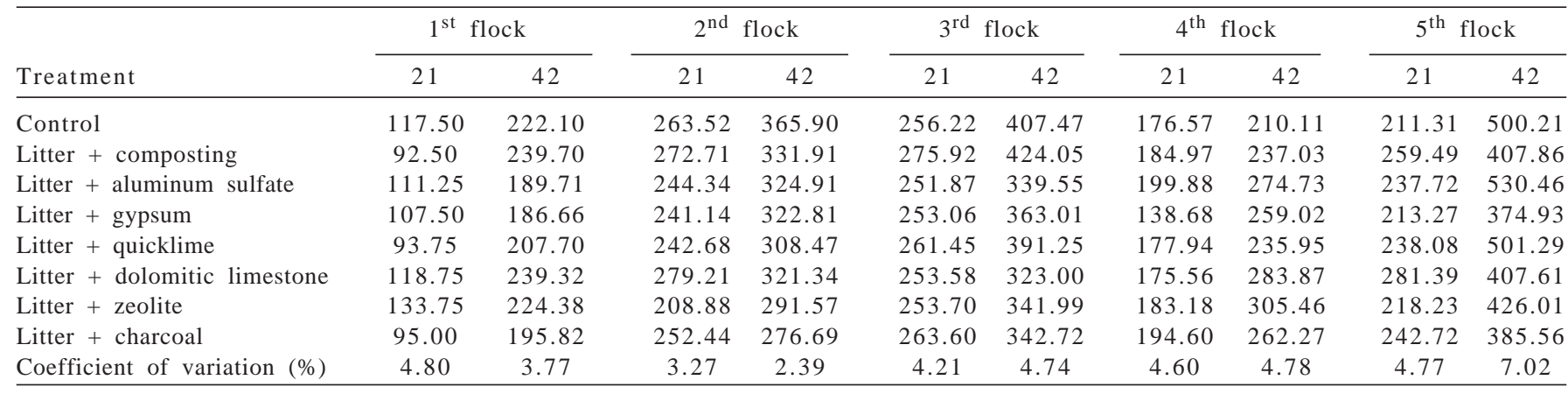


that the moisture content of litters did not vary at 35, 42 and 49 days of breeding, remaining from 18 to $10 \%$.

At 21 days of breeding, treatment with aluminum sulfate caused a decrease $(\mathrm{P}<0.01)$ in $\mathrm{pH}$ of the litters for all flocks and, at 42 days, $\mathrm{pH}$ of the litter reduced $(\mathrm{P}<0.02)$ in litters treated with aluminum sulfate and gypsum for the first, second and fourth flocks (Table 3). At 21 days of breeding, treatment using aluminum sulfate reduced $(\mathrm{P}<0.02)$ the volatilized ammonia levels for the first, third and fourth flocks and, at 42 days, there was a reduction $(\mathrm{P}<0.02)$ in the volatilized ammonia in litters treated with aluminum sulfate only for the fourth flock (Table 4).

Nitrogen conversion of excretes into ammonia is related to the temperature, humidity and $\mathrm{pH}$ of litter and to the ventilation rate (Miles, 2008). Acidic treatments for poultry litter reduce volatile ammonia by decreasing $\mathrm{pH}$, which, in turn, changes the $\mathrm{NH}_{4}{ }^{+} / \mathrm{NH}_{3}$ balance towards the formation of more non-volatile $\mathrm{NH}_{4}{ }^{+}$. Ammonia volatilizes because it lacks electric charge (Moore Junior et al., 2000).

Similar results were obtained by Maurice et al. (1998) when using zeolite. Authors supplemented wood shaving litter with zeolite ( $10 \%$ of the litter weight) and did not notice effects on $\mathrm{pH}$ and volatilized ammonia. Also Oliveira et al. (2004), studying the utilization of aluminum sulfate, superphosphate and hydrated lime in litters submitted to three flocks reported that the smallest values of $\mathrm{pH}$ were obtained by using aluminum sulfate (7.42; 7.07; and 6.00, respectively for the first, second and third flocks) at 42 days of breeding. Likewise, there was a reduction on volatilized ammonia due to the aluminum sulfate utilization for the three flocks.

Nagaraj et al. (2007) evaluated the effects of sodium bisulfate in poultry litter and reported that ammonia levels were smaller for treated litters in comparison to those untreated until 35 days of breeding.

Sims \& Luka-McCafferty (2002) and Kim \& Choi (2009) evaluated the utilization of aluminum sulfate in poultry litter and also observed a $\mathrm{pH}$ reduction in litters in comparison to the untreated litters. Kim \& Choi (2009) also reported an increase in $\mathrm{NH}_{4}{ }^{+}$ions in the litter through the utilization of aluminum sulfate in the third week of breeding ( 2 and $6.3 \mathrm{~g} / \mathrm{kg}$ for untreated litter and treated litter using 3.5\% of aluminum sulfate, respectively). On the other hand, Medeiros et al. (2008) evaluated the inclusion of superphosphate $(0,5,10$, 15,20 and 25\%) in litters from four cycles and reported that volatilized ammonia decreased after the inclusion of $15 \%$ and $\mathrm{pH}$ linearly reduced from 8.4 (05) to 5.8 (25\%) as the inclusion of conditioner increased.

Table 3 - pH value of poultry litters, at 21 and 42 days of breeding, submitted to different treatments during five consecutive flocks

\begin{tabular}{|c|c|c|c|c|c|c|c|c|c|c|}
\hline Treatment & \multicolumn{2}{|c|}{$1^{\text {st }}$ flock } & \multicolumn{2}{|c|}{$2^{\text {nd }}$ flock } & \multicolumn{2}{|c|}{$3^{\text {rd }}$ flock } & \multicolumn{2}{|c|}{$4^{\text {th }}$ flock } & \multicolumn{2}{|c|}{$5^{\text {th }}$ flock } \\
\hline Control & $8.71 \mathrm{a}$ & $8.89 \mathrm{a}$ & $8.84 a$ & $9.17 \mathrm{a}$ & $9.69 a$ & 9.22 & $8.84 a$ & $9.51 \mathrm{ab}$ & $9.13 \mathrm{a}$ & 9.05 \\
\hline Litter + aluminum sulfate & $4.33 b$ & $8.62 b$ & $7.33 b$ & $8.72 b$ & $7.67 b$ & 9.10 & $7.32 b$ & $8.56 c$ & $7.85 b$ & 8.83 \\
\hline Litter + gypsum & $8.35 a$ & $8.57 \mathrm{~b}$ & $8.26 a$ & $8.72 b$ & $9.25 a$ & 9.17 & $8.21 \mathrm{a}$ & $8.76 c$ & $8.80 \mathrm{a}$ & 9.32 \\
\hline Litter + quicklime & $9.17 a$ & $9.37 \mathrm{a}$ & $8.96 a$ & $9.24 \mathrm{a}$ & $9.83 a$ & 9.37 & $9.04 a$ & $9.41 \mathrm{~b}$ & $9.24 a$ & 8.68 \\
\hline Litter + charcoal & $9.03 a$ & $9.54 \mathrm{a}$ & $8.89 a$ & $9.18 \mathrm{a}$ & $9.61 \mathrm{a}$ & 9.27 & $9.07 \mathrm{a}$ & $9.65 a b$ & $9.10 \mathrm{a}$ & 9.33 \\
\hline Coefficient of variation (\%) & 7.96 & 3.48 & 5.55 & 1.78 & 9.16 & 2.49 & 4.31 & 2.05 & 3.30 & 3.02 \\
\hline
\end{tabular}

Means followed by different letters in columns are different $(\mathrm{P}<0.02)$ by Tukey test.

Table 4 - Volatilized ammonia values (ppm) of poultry litter of broilers at 21 to 42 days of breeding submitted to different treatments during five consecutive flocks

\begin{tabular}{|c|c|c|c|c|c|c|c|c|c|c|}
\hline \multirow[b]{2}{*}{ Treatment } & \multicolumn{2}{|c|}{$1^{\text {st }}$ flock } & \multicolumn{2}{|c|}{$2^{\text {nd }}$ flock } & \multicolumn{2}{|c|}{$3^{\text {rd }}$ flock } & \multicolumn{2}{|c|}{$4^{\text {th }}$ flock } & \multicolumn{2}{|c|}{$5^{\text {th }}$ flock } \\
\hline & 21 & 42 & 21 & 42 & 21 & 42 & 21 & 42 & 21 & 42 \\
\hline Control & $176.82 \mathrm{a}$ & 87.34 & 25.87 & 76.43 & $26.75 a$ & 86.61 & $33.86 a$ & 57.28a & 88.87 & 204.26 \\
\hline Litter + composting & $104.22 \mathrm{ab}$ & 206.31 & 29.38 & 86.78 & 21.51a & 101.52 & $22.71 \mathrm{a}$ & $43.90 a$ & 64.86 & 218.43 \\
\hline Litter + aluminum sulfate & $39.36 b$ & 95.39 & 27.19 & 63.84 & $3.77 \mathrm{c}$ & 75.53 & $7.07 \mathrm{~b}$ & $21.38 b$ & 40.35 & 144.28 \\
\hline Litter + gypsum & $47.07 \mathrm{ab}$ & 153.82 & 27.27 & 63.68 & 10.56ab & 66.17 & 17.58ab & $35.15 a b$ & 79.91 & 185.25 \\
\hline Litter + quicklime & $96.70 \mathrm{ab}$ & 117.09 & 49.63 & 88.57 & 19.38a & 54.05 & $31.70 \mathrm{a}$ & $55.70 \mathrm{a}$ & 88.66 & 215.64 \\
\hline Litter + dolomitic limestone & $95.48 \mathrm{ab}$ & 119.97 & 41.99 & 67.32 & $9.86 \mathrm{ab}$ & 92.47 & $31.65 \mathrm{a}$ & 30.98ab & 88.72 & 127.15 \\
\hline Litter + zeolite & $68.00 \mathrm{ab}$ & 112.43 & 36.97 & 74.24 & 21.18a & 113.76 & $32.00 \mathrm{a}$ & $37.31 \mathrm{ab}$ & 75.15 & 274.18 \\
\hline Litter + charcoal & $127.86 a b$ & 205.95 & 36.65 & 81.80 & $13.54 \mathrm{a}$ & 72.93 & $36.40 \mathrm{a}$ & $44.04 \mathrm{a}$ & 105.52 & 245.08 \\
\hline Coeficient of variation (\%) & 13.42 & 15.47 & 23.44 & 6.72 & 17.70 & 12.29 & 13.11 & 11.44 & 12.67 & 12.26 \\
\hline
\end{tabular}

Means followed by different letters in columns are different $(\mathrm{P}<0.02)$ by Tukey test. 
Aluminum sulfate provides protons to the environment. The mechanism of ammonia removal from the environment is given by the reaction with gaseous ammonia $\left(\mathrm{NH}_{3}\right)$ in order to form the non-volatile cation ammonium $\left(\mathrm{NH}_{4}^{+}\right)$. However, ammonia decrease is not directly associated to the reduction on $\mathrm{pH}$ of the litter. The effect of these litter conditioners on ammonia levels lasts longer than the time usually observed for $\mathrm{pH}$ decrease. This finding suggests that $\mathrm{pH}$ reduction might not be an exclusive mechanism over this process.

Alkaline substances as quicklime and gypsum also may interfere in litter quality. Oliveira et al. (2003) compared new litter with reused litter, with and without treatment (gypsum and hydrated lime). Authors observed that the smallest $\mathrm{pH}$ value (6.97) and the smallest volatilized ammonia level (112.9 ppm) were obtained for litter treatment by using gypsum, due to its greater ability to retain humidity. As a consequence, ammonia-producing bacteria had its survival decreased. Quicklime, an alkaline substance, creates a favorable environment, as a matter of $\mathrm{pH}$, for the loss of ammoniacal nitrogen of litter through volatilization.

Ruiz et al. (2008) used quicklime at the proportions of 10 and $15 \%$ of the litter weight and did not detect differences concerning the moisture content values, although $\mathrm{pH}$ values differed from those obtained for the untreated litter. There was an increase on $\mathrm{pH}$ from 7.65 to 8.38 and 8.75 , respectively, for untreated litter and litter treated with 10 an $15 \%$ of quicklime.

It was already expected a decrease in the volatilized ammonia of litters treated with zeolite. According to Liang et al. (2005), zeolite has the ability to absorb ammonia. However, this effect was not observed. Topic application of zeolite in fresh dejects of layer hens reduced ammonia emission during a stocking period of 14 days in 66, 91 and $96 \%$ for the applications rates of 2.5, 5 and $10 \%$ respectively (Li et al., 2008). There are two viewpoints on the mechanisms of action of zeolite. First, ammonia binds to zeolite, leading to the elimination of the toxic effects of $\mathrm{NH}_{4}{ }^{+}$produced by the intestinal microbial activity and second, zeolite delays digesta transit resulting in a more efficient utilization of dietary nutrients (Olver, 1997).

Miles (2008) used wood shavings litter submitted to two flocks and in-house composting during the period between flocks. Authors reported that on the surface of the composting pile ammonia average concentration is greater $(11.2 \mathrm{ppm})$ than inside the pile (4.4 ppm). This finding emphasizes the hypothesis that birds are exposed to greater ammonia concentrations that may not be contemplated by the measures performed above them.
Results of poultry litter quality obtained through the utilization of dolomitic limestone and charcoal were not found in the literature. Both substances are known to have the ability to absorb humidity (Alcarde et al., 1992; Souza et al., 2009), which might bring benefits concerning volatilized ammonia reduction, although this effect did not occur.

\section{Conclusions}

Aluminum sulfate is feasible of being used as conditioner for poultry litter made of chopped elephant grass due to its properties of reducing $\mathrm{pH}$ and volatilized ammonia.

\section{Acknowledgements}

The authors thank Perdigão S.A. for the donations of birds used in this experiment.

\section{References}

ALCARDE, J.C.; MALAVOLTA, E.; BORGES, A.L. et al. Avaliação da higroscopicidade de fertilizantes e corretivos. Scientia Agrícola, v.49, n.1, p.137-144, 1992.

DE-ROUCHEY, J.M.; HARNER, J.P.; MURPHY, J.P. Catastrophic mortality composting: is it safe and effective? Journal of Applied Poultry Research, v.14, n.2, p.414-416, 2005.

DO, J.C.; CHOI, I.H.; NAHM, K.H. Effects of chemically amended litter on broiler performances, atmospheric ammonia concentration, and phosphorus solubility in litter. Poultry Science, v.84, n.5, p.679-686, 2005.

ELEROGLU, H.; YALÇIN, H. Use of natural zeolite-supplemented litter increased broiler production. South African Journal of Animal Science, v.35, n.2, p.90-97, 2005.

HUFF, W.E.; MOORE JUNIOR, P.A.; BALOG, J.M. et al. Evaluation of the toxicity of alum (aluminum sulfate) in young broiler chicks. Poultry Science, v.75, n.11, p.1359-1364, 1996.

KIM, Y.J.; CHOI, I.J. Effect of alum and liquid alum on pH, EC, moisture, ammonium and soluble phosphorus contents in poultry litter during short term: a laboratory experiment. Journal of Poultry Science, v.46, n.1, p.63-67, 2009.

KOERKAMP, P.W.G.G.; MIDDELKOOP, J.H.; ELLEN, H.H. Air quality management and requirements in Europe. In: NATIONAL POULTRY WASTE MANAGEMENT SYMPOSIUM, 2000, Auburn. Proceedings... Auburn: Auburn University, 2000. p.72-79.

LI, H.; XIN, H.; LIANG, Y. et al. Reduction of ammonia emissions from stored laying hen manure through topical application of zeolite, Al+Clear, Ferix-3, or poultry litter treatment. Journal of Applied Poultry Research, v.17, n.4, p.421-431, 2008.

LIANG, Y.; XIN, H.; LI, H. et al. Evaluation of treatment agents and diet manipulation for mitigating ammonia and odor emissions from laying hen manure. In: ANNUAL INTERNATIONAL MEETING, 2005, Florida. Proceedings... Florida: ASABE, 2005. Paper no 054160.

LIEN, R.J.; HESS, J.B.; CONNER, D.E. et al. Peanut hulls as a litter source for broiler breeder replacement pullets. Poultry Science, v.77, n.1, p.41-46, 1998.

LINE, J.E. Campylobacter and Salmonella populations associated with chickens raised on acidified litter. Poultry Science, v.81, n.10, p.1473-1477, 2002 
MACKLIN, K.S.; HESS, J.B.; BILGILI, S.F. et al. Effects of inhouse composting of litter on bacterial levels. Journal of Applied Poultry Research, v.15, n.4, p.531-537, 2006.

MAURICE, D.V.; LIGHTSEY, S.F.; HAMRICK, E. et al. Alum sludge and zeolite as components of broiler litter. Journal of Applied Poultry Research, v.7, n.3, p.263-267, 1998.

MEDEIROS, R.; SANTOS, B.J.M.; FREITAS, M. et al. Additon of chemical additives and the effect of moisture in the volatilization of ammonia in poultry litter. Ciência Rural, v.38, n.8, p.2321-2326, 2008.

MILES, D.M. Vertical stratification of ammonia in a broiler house. Journal of Applied Poultry Research, v.17, n.3, p.348-353, 2008.

MOORE JUNIOR, P.A.; DANIEL, T.C.; EDWARDS, D.R. Reducing phosphorus runoff and inhibiting ammonia loss from poultry manure with aluminum sulfate. Journal of Environmental Quality, v.29, n.1, p.29-37, 2000.

NAGARAJ, M.; WILSON, C.A.P.; SAENMAHAYAK, B. et al. Efficacy of a litter amendment to reduce pododermatitis in broiler chickens. Journal of Applied Poultry Research, v.16, n.2, p.255-261, 2007.

OLIVEIRA, M.C.; ALMEIDA, C.V.; ANDRADE, D.O. et al. Dry matter content, $\mathrm{pH}$ and volatilized ammonia from poultry litter treated or not with different additives. Revista Brasileira de Zootecnia, v.32, n.4, p.951-954, 2003.

OLIVEIRA, M.C.; FERREIRA, H.A.; CANCHERINI, L.C. Effect of chemical conditioners on poultry litter quality. Arquivo Brasileiro de Medicina Veterinária e Zootecnia, v.56, n.4, p.536-541, 2004.
OLVER, M.D. Effect of feeding clinoptilolite zeolite on the performance of three strains of laying hens. British Poultry Science, v.38, n.2, p.220-222, 1997.

REECE, F.N.; BATES, B.J.; LOTT, B.D. Ammonia control in broiler houses. Poultry Science, v.58, n.6, p.754-755, 1979.

RUIZ, V.; RUIZ, D.; GERNAT, A.G. et al. The effect of quicklime $(\mathrm{CaO})$ on litter condition and broiler performance. Poultry Science, v.87, n.5, p.823-827, 2008.

SILVA, D.J.; QUEIROZ, C.A Análise de alimentos: métodos químicos e biológicos. 3. ed. Viçosa, MG: Editora UFV, 2002. 235p.

SIMS, J.T.; LUKA-McCAFFERTY, N.J. On-farm evaluation of aluminum sulfate (alum) as a poultry litter amendment: effects on litter properties. Journal of Environmental Quality, v.31, n.6, p.2056-2073, 2002.

SOUZA, M.A.S.; CASTRO, N.; ÁVILLA, F.L. Construção de um secador solar de madeira em escala experimental. In: MOSTRA INSTITUCIONAL UFAM/UEA, 2., 2009, Itacoatiara, AM. Anais eletrônicos... Itacoatiara: UEA, 2009. Disponível em: <http:// www.icet.ufam.edu.br/semanact2009/resumos/Resumo\%20 Marcos\%20Antonio.pdf>. Acesso em: 9/3/2010.

TURAN, N.G. The effects of natural zeolite on salinity level of poultry litter compost. Bioresource Tecnology, v.99, n.7, p.2097-2101, 2008.

UNIVERSIDADE FEDERAL DE VIÇOSA - UFV. Sistema de Análises Estatísticas e Genéticas - SAEG. Versão 8.0. Viçosa, MG, 2001. 150p.

WILKINSON, K.G. The biosecurity of on-farm mortality composting. Journal of Applied Microbiology, v.102, n.3, p.609-618, 2007.

WORLEY, J.W.; CABRERA, M.L.; RISSE, L.M. Reduced levels of alum to amend broiler litter. Applied Engineering in Agriculture, v.16, n.4, p.441-444, 2000. 